\title{
A Perspective on the Economics of Natural Gas Decontrol
}

\author{
MACK OTT and JOHN A. TATOM
}

\begin{abstract}
叠
FUNDAMENTAL lesson that economic policymakers learned over the past decade is that microeconomic energy policies can have a significant effect on the nation's macroeconomic performance. Early in the decade, price regulation in domestic energy markets led to growing imports of energy and rendered the United States - the world's largest energy producerimpotent to the challenge of the OPEC cartel in determining the prices of the world's energy resources. Subsequent policy efforts to smooth the difficult transition to a world of higher-cost energy by preventing any abrupt rise in domestic energy prices reduced the incentive to conserve energy, discouraged domestic energy production, subsidized petroleum imports and increased inefficiencies in the use of domestic energy supplies.
\end{abstract}

These policies increased the demand for OPEC petroleum so that the ability of the OPEC cartel to raise its prices (and thereby reduce world output and raise the dollar prices of goods and services) was substantially enhanced. ${ }^{\prime}$ Moreover, attempts to smooth the disruptive effects of OPEC actions could not keep pace with the changing realities in world energy markets. The energy prices assumed to prevail at the end of each transition continually fell short of the market price, contrary to federal energy policy intentions.

The elaborate regulatory scheme for oil was finally abandoned in February 1981. In the case of natural gas, the recognition that regulations were leading to

\footnotetext{
'See John A. Tatom, "Energy and Its Impact on Economic Growth: A Supply-Side Miracle for the Eighties," Federal Reserve Bank of St. Louis, Working Paper 82-005, 1982. Also Claudio Loderer, "Theory and Evidence about the Structure of the International Oil Market: 1974-1979," Graduate School of Management, University of Rochester, Working Paper GPB 82-5, 1982, provides evidence that $O P E C$ has operated sucessfully as a cartel but that this alone has not accounted for higher energy prices. He emphasizes that energy policies worldwide have contributed to higher prices in the manner detailed below.
}

increased shortages of gas and a consequent increased reliance on imported oil led to the passage of the Natural Gas Policy Act of 1978 (NGPA). Akin to the earlier efforts to prevent abrupt energy price increases in the transition to a free market for oil, NGPA provided for phased decontrol of the nation's natural gas market. Changing world energy market conditions, however, rendered this plan obsolete as the pace of allowable price increases and decontrol became inadequate to accomplish a smooth transition. In addition, there emerged a growing recognition that phased policy changes create perverse economic incentives that thwart the achievement of the policy objectives. ${ }^{2}$ As a result, pressure has been growing to decontrol natural gas markets more rapidly than scheduled under NGPA.

A major obstacle to the decontrol of the U.S. natural gas market has been the potential effect on the price of natural gas paid by residential users (voters). Analysts also have argued that natural gas decontrol will have adverse macroeconomic effects similar to those experienced following OPEC energy price increases.

This article provides an alternative perspective, which indicates that the adverse economic effects of decontrol are substantially overstated. These negative impacts are largely reversed when the effect of natural gas decontrol on the world oil market is taken into account. $^{3}$

\footnotetext{
${ }^{2}$ Knowing that future prices will be higher than current prices, gas producers are induced to postpone production of some known or suspected deposits until after decontrol. This reduces the predecontrol supply of gas and increases scarcity. Thus, the phased decontrol of prices, instead of smoothing the transition, actually worsens the domestic gas shortage.

${ }^{3}$ This article draws heavily upon the more detailed analysis in Mack Ott and John A. Tatom, "Are There Adverse Inflation Effects Associated with Natural Gas Decontrol?" Contemporary Policy Issues, a supplement to Economic Inquiry (October 1982), pp. $27-46$.
} 


\section{Table 1}

\begin{tabular}{|c|c|c|c|c|c|c|c|}
\hline & 1950 & 1955 & 1060 & 1965 & 1970 & 1975 & 1980 \\
\hline Total energy & 3362 & 39,8 & 4408 & 5299 & 6683 & 707 & 7227 \\
\hline Natural gas & 597 & 9.00 & 1239 & 157 & 2179 & 1995 & 2044 \\
\hline $\begin{array}{l}\text { Naturargas as } \\
\text { a percent ol } \\
\text { lolal energy }\end{array}$ & $178 \%$ & $230 \%$ & $281 \%$ & $298 \%$ & $326 \%$ & $282 \%$ & 2680 \\
\hline \multicolumn{8}{|c|}{ SHARE OF NATURAL GAS USE BY SEOTOR? } \\
\hline Tesidental & $208 \%$ & $243 \%$ & $259 \%$ & $255 \%$ & $229 \%$ & $252 \%$ & $240 \%$ \\
\hline Commercial & 67 & 72 & 86 & 04 & 113 & 12.8 & 135 \\
\hline noustral & 59.4 & 522 & 482 & 46,5 & 438 & 42,8 & 111 \\
\hline Elecrro utuly & 109 & 132 & 144 & 152 & 186 & 162 & 184 \\
\hline $\begin{array}{l}\text { Transportation } \\
\text { (pipeline) }\end{array}$ & 22 & 29 & 29 & 33 & 34 & 30 & 29 \\
\hline & $1000 \%$ & $1000 \%$ & $1000 \%$ & $1000 \%$ & $1000 \%$ & $1000 \%$ & $1000 \%$ \\
\hline
\end{tabular}

A quad is one guedrilion Britsh themal units.

Totals may not add to 100 oue 10 rounding

SOURCE Energy Infornation Adminstration, US Department of Energy, 1980 Annual fepon to Congress, volume 2 and Monthy Energy hewew.

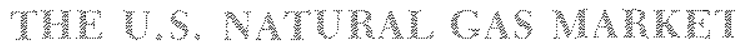

From 1950 to 1970 , the domestic consumption of all types of energy grew at an average annual rate of 3.5 percent, with natural gas consumption growing at a 6.7 percent rate. The growth of both total energy and natural gas consumption was particularly rapid during the $1960 s$, before slowing dramatically in the past decade. As table 1 shows, consumption of natural gas as a fraction of total energy rose from about one-sixth in 1950 to about one-third in 1970 , then declined to slightly over one-fourth in 1980.

In large part, the decline in the growth of natural gas consumption was the result of governmental control of the pricing and distribution of natural gas. ${ }^{4}$ Control of wellhead natural gas prices from the early 1960 s led to declining reserves of natural gas relative to its production and, since 1968 , absolutely declining reserves. In addition, the number of new gas wells drilled declined

\footnotetext{
"See Jai-Hoon Yarg, "The Nature and Origins of the U.S. Energy Crisis," this Review (July 1977), pp. 2-12, and Panl W. MacAvoy and Robert $\mathrm{S}$. Pindyck. The Economics of the Natural Gas Shortage (1960-1980) (North-Holland Publishing Company, 1975), especially chapter 1, pp. $1-28$.
}

from 1962 to 1968 . Production growth actually did not begin to decline until after 1973 when the excess inventories (reserves) caused by regulatory changes in the early 1960 s had been eliminated. In the early 1970 s, natural gas prices began to respond to the growing shortage. Nevertheless, production continued to decline until the passage of NGPA and the related Powerplant and Industrial Fuel Use Act of 1978 (FUA).

These laws lessened restrictions on the pricing of natural gas, decontrolled the price of new gas from deep wells and other high-cost gas, but extended restrictions on the industrial and utility use of natural gas and on the construction of new gas-fived boilers. The phase-out of wellhead price controls, to be completed by the end of 1984 , presumed that gas would then sell at the equivalent of a relatively low 1984 price of crude oil. The limitations on industrial and utility gas demand, in practice, allow such uses residually; that is, they allow exceptions to the restrictions only to the extent that other uses of gas do not exhaust total natural gas production.

Table 1 shows that the total use of natural gas was lower in 1975 than in 1970. Natural gas use rose following the enactment of NGPA, although the share of gas 
Table 2

The Real Price of Natural Gas ${ }^{1}$-Delivered to Final Users and at the Wellhead \$/1000 (cubic ft)

\begin{tabular}{|c|c|c|c|c|c|c|c|c|}
\hline & 1950 & 1955 & 1960 & 1965 & 1970 & 1975 & 1080 & 1981 \\
\hline Besidential & 1288 & 1460 & 1505 & 1400 & 1192 & 1360 & 2076 & 2214 \\
\hline Cortnerctal & 0888 & 1,031 & 1128 & 1039 & 084 & 1075 & 1913 & 2065 \\
\hline Electric utilities & 0355 & 0485 & 0582 & 0,514 & 0374 & 0,702 & $\begin{array}{l}1,689 \\
1256\end{array}$ & 1546 \\
\hline $\begin{array}{l}\text { Transportation } \\
\text { (opeline) }\end{array}$ & $\mathrm{NA}$ & NA & $\mathrm{NA}$ & $\mathrm{NA}$ & 0230 & 0314 & 1041 & 1235 \\
\hline Wellhead & 0121 & 0171 & 0204 & 0210 & 0187 & 0354 & 09904 & 1030 \\
\hline
\end{tabular}

The ratio 0 the ndicated price to the implict price deflator for GNP 1972 plices

Industrial and electric utility prices are not avaliable separately prior to 1967 , the prices tor 1950 , 65 are average prices for thaustral and utily customers.

3 Pipeline vel price is not available pror to 1967

SOURCES Energy Intormation Adninistration, US Departuent of Energy Annual Peport to Con gress, 1977 and 980 . Monthy Energy Revew (August 1982).

in total energy still declined slightly. The tilt toward residential use of natural gas and away from industrial use (especially electric utility use) before NGPA also can be seen by comparing the pattern of use in 1975 with that in earlier years. Despite the rise in the residential share from 1970 to 1975 , total residential use was virtually unchanged. Residential use declined only after NGPA, while electric utility use recovered sharply. Since utility use is restricted to the residual after residential demands, increased use by utilities would not have been possible without the combined effects of increased total gas production and reduced demand by other, primarily residential, users.

The decline in the growth of natural gas consumption also is due to a rise in the delivered price of gas, primarily since the OPEC embargo of 1973-74. As table 2 reveals, the real price of natural gas rose significantly from 1950 to 1960 for all users, then declined to a level in 1970 roughly equal to its 1950 value. From 1970 to 1980 , however, the real price of delivered natural gas rose dramatically, almost doubling for residential users and rising by even larger multiples for the commercial, industrial, utility and pipeline sectors.

During the $1950-70$ period, the real wellhead price of gas rose at only a 2.2 percent rate, but then surged at a 15.8 percent rate from 1970 to 1980 , or, even more revealing, an 18.8 percent rate from 1975 to 1980 . The percentage movements in the industrial and electric utility prices conformed closely to the growth rate of the wellhead price during the $1950-70,1970-80$ and 1975-80 subperiods. In contrast, residential prices grew much more slowly than the wellhead or delivered industrial prices.

The diversity of delivered natural gas prices reflects different delivery and administrative costs. Decontrol of the wellhead price of natural gas will not raise the price for each of the various users of natural gas to the same extent because of these differences. In the industrial and utility sectors, the share of the wellhead cost of gas in the delivered price is very high, so that percentage changes in the wellhead price result in similar percentage changes in delivered price. The share of the wellhead cost of gas in the delivered price to residential customers is much smaller, as can be seen from the difference in relative prices; a given percentage change in the wellhead price leads to a much smaller percentage change in the residential price.

The effect of controls on natural gas prices appears to have been quite extensive, especially since 1973 , yet gas fuel prices have risen more rapidly than crude oil over the last 12 years. Chart 1 shows an index of the real price of gas, found by deflating the producer price index (PPI) of gas fuels by the implicit price deflator for private business sector output, and an index of the real price of crude petroluem, the PPI for erude petroleum, adjusted for the crude oil control program, de- 


\section{Chart 1 \\ Index of the Relative Prices of Gas and Oil}

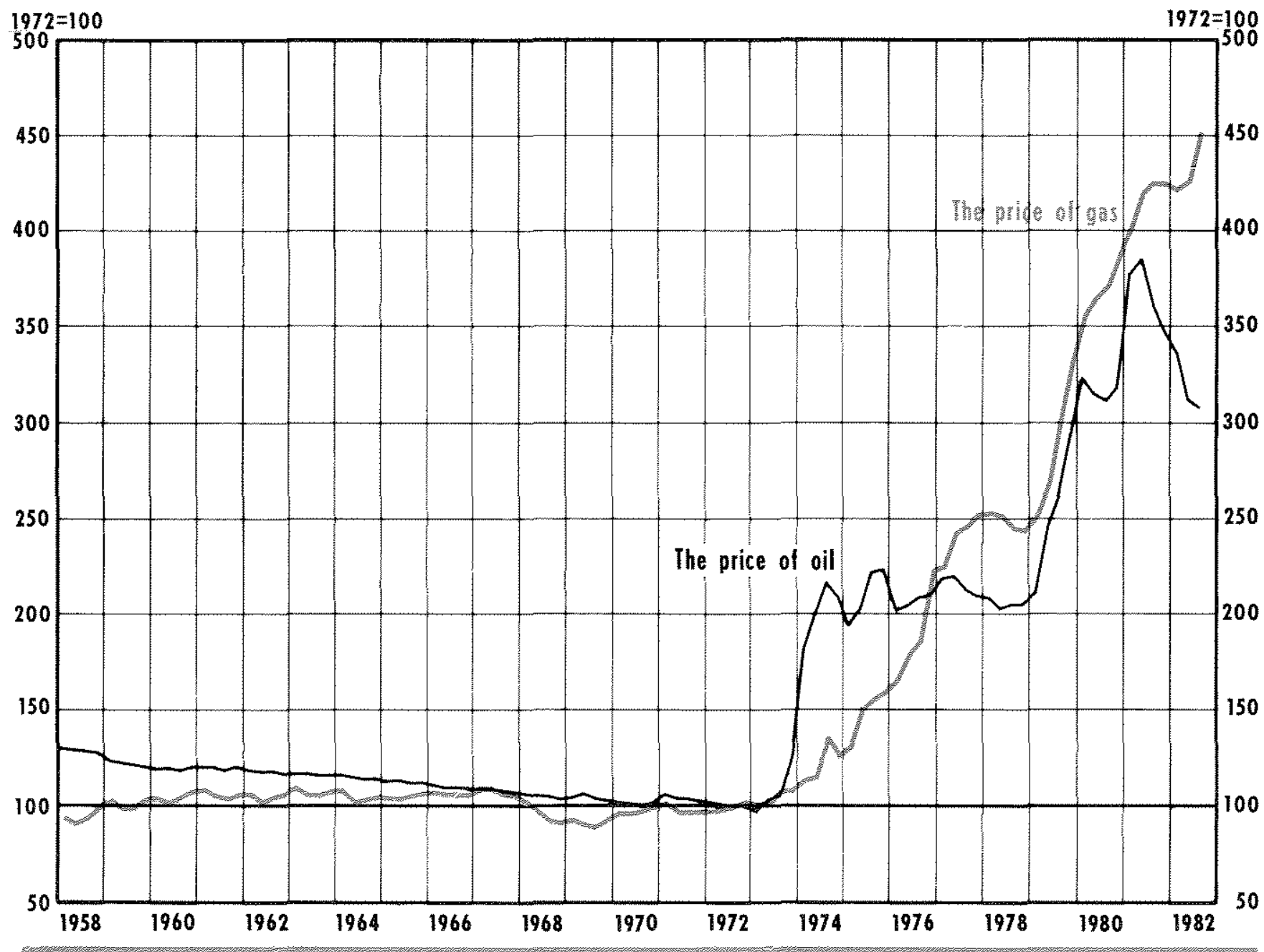

flated by the same price index. ${ }^{5}$ In 1981, the index for the price of gas was somewhat above that of crude oil. The delayed response of gas prices to the 1973-74 run-up in the real price of crude in the United States can be observed in chart 1. In 1977-78. however, when real ofl prices flattened out the price of gas changed little, despite the considerable leeway exhibited earlier for regulated real gas prices to rise. From mid-1981 to mid-1982, when real crude prices fell, the rise in natural gas prices slowed shaply. Such casual evidence raises doubts about the usefulness of extrapolat-

The crude oil price is adjusted to refect the actual cost of oil to refiners rather than domestic sellon pres. The difference arises from the entitement system. The entitlement aljustment simply atds the differential between the logarithn of the composite refiner acquistion cest of ende oil and the domestic refine? acunisition cost to the logarithm of the Ply for etuds oil. ing "controlled" natural gas prices upward based upon regulatory allowances.

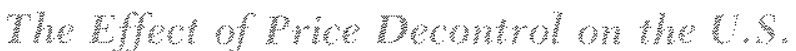

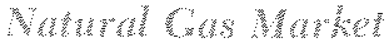

In some essential respects (i.e., at the margin), natural gas was decontrolled in November 1979 when the wellhead prices of new (discovered since February 19 , 1977), deep (15,000 feet or more), and other high-cost gas were totally decontrolled by NGPA ${ }^{*}$ On the other

\footnotetext{
See Energy Information Administration, U.S. Department of Energy, Amual Repot to Congress $198 \mathrm{lb}$, pp. 2-3, for a solyedule of eeiling prices under NGPA. of conrse. imports of natural gas, especially fom Comata and Mexice, are free of U.S. wellhead price controls and tend to be priced accorting to the world price of oil. Such imports gemerally have beer less than 5 percent of comsumption.
} 
hand, some categories of natural gas remain subject to wellhead price ceilings that will ikely be effective well beyond this decade. For the puposes of the analysis in this article, decontrol refers to the complete abandonment of wellhead price regulation and the repeal of FUA. The hypotheses developed below already apply to post-1977 developments under phased decontrol.

There are two shortage-creating effects of any price control program that holds a price below its marketclearing level. The first effect is that less of that good will be produced than would be at the higher price. Removing the controls increases the quantities supplied. In the case of natural gas, the potential increment to supply comes from three sources: (1) known gas deposits recoverable at ligher cost but not profitable to produce at the current controlled price-or more profitable to produce later when prices are expected to be higher; (2) suspected gas deposits whose anticipated development and production cost could not be covered at current prices; (3) a shift in prodaction techniques so that currently producing oil wells would produce, at a higher price of gas relative to that of crude oil, less ofl and more gas.

The second effect of a price control program is that a larger quantity of that good will be demanded than at the higher market-clearing price so that, to be effective, the price control program must ilvolve an allocation or rationing scheme. Evidence of this rationing is apparent in the different prices in the intrastate and the interstate markets.

During the $1960-78$ period, the intrastate natual gas markets were free of controls so that purchasers could avoid rationing by paying a market clearing price-limited only by the cost of competing fuelsand suppliers could respond to these higher prices. $\mathrm{O}$ of course, the diversion of supplies to this market intensified the shortage in the regulated interstate market. The intrastate market, primarily in Texas, Oklahoma

\footnotetext{
"See Paul Bennett and Debra Kuenstner, "Natural Cas Controls and Decontrol,"Federal Reserve Bank of New York Quarterly Reviru (Winter 1981-82), pp. 50 60. They cite studies indieating that by 1990,28 to 38 percent of natural gas wouk remain ontrolled inder NGPA.

sarthermore, the availability of gas at a market dearing price in these intrastate natrets probably induced some firms to relocate. The lower likethood of interupted natural gas simplifies producton decsions and long-renge planning by reducing energy uncertainty. This is part of the favorable impact of natural gas deregulation on the Northeast region predicted by Joseph Kalt Heny Lee and Robert A. Jeone, Natural Cas Decontrol: A Northeast Industrial Perspective Energy and Envirommental Policy Center, Harvard University, July 1982 .
}

Table 3

Natural Gas Price Paid by Electric Utilities in Interstate and Intrastate Markets (dollars per 1000 cubic feet) and Residual Fuel Oil Price

Pr
m

and Louisiana, had gas prices during this period substantially in excess of the interstate market.

As shown in table 3 , electric utilities willingly paid a much higher price for natural gas in the intrastate market than they paid in the interstate market. Note that the average price of gas in the intrastate market was close to the BTU-equivalent cost of fuel oil. When NGPA brotght the intrastate market under federal price control, the difference between the intra- and interstate prices effectively was nullified. The implication of the earlier, sharply higher, uncontrolled intrastate gas prices and the recent discrepancy between the price of fuel oil and the prices of gas is that gas has been inefficiently allocated to lower-valued uses. ${ }^{9}$

\section{The Conventional Analysis of Decontrol}

Most analyses of natural gats deregulation have assumed that, measured on a BrU basis, the price of natural gas and fuel oil at the bumer-tip would be equated and that the price of natural gas would rise to equality with an unchanged fuel oil price. The underlying presumption has been that natural gas and petroleum fuels are highly substitutable for gas; thus, it is argued that deregulation would cause natural gas wellhead prices to rise until delvered gas prices, especially

\footnotetext{
See Energy Infornation Administmation, U.S. Department of Energy, Analusis of Economic Effects of Accelerated Deregulation of Natural Gas Prices (August 1981) p. 28.
} 
Table 4

A Conventional Analysis of Natural Gas Decontrol-Constant Oil Prices (IV/1981)

\begin{tabular}{|c|c|c|c|c|}
\hline & & 141980 & Deconirot & $\begin{array}{l}\text { Percent } \\
\text { change }\end{array}$ \\
\hline $\begin{array}{l}\text { Price of residual fuel ol deinered } \\
\text { lo steam electric uifity pants }\end{array}$ & Shotrel & $\$ 32,00$ & \$3,, $100^{\prime}$ & 0 \\
\hline Price of ratural gas, stean & Snct & 4.07 & + & $726 \%$ \\
\hline Welhead price of natural gas & Smat & 2,15 & 4308 & 1037 \\
\hline Price of natiral gas, average & Simel & 485 & 6.908 & 460 \\
\hline
\end{tabular}

Conversion tactors:

Residual fuel olt, 6.244 noisand BhUbartel

Natural ges electic utilies, 1034 E Tuloublc tool

Natural gas production, $1026 \mathrm{BT}$ U/cubic tool

Naturat gas residential, 1,026 BTU cubic toot

Sounde. Northiy Energy Review (September 1982)

for utilities and industrial users, are equivalent to the price of fuel oil.

As shown in table 1, electric utilities use a significant share of U.S. natural gas. In addition, natural gas is an important source of fuel for the generation of electricity. Natural gas, which constituted 18.7 percent of the energy input used by electric utilities in 1973, declined to 14.0 percent in 1978 before NGPA loosened quantitative restraints on gas use and allowed this proportion to rise back to 15 percent by 1981 . In 1973 , petroleum was slightly less important in electric utility production, remained so until 1975 , brieffy became relatively larger than gas use in 1976-78, then declined sharply to 1981 as a share of electric utility energy consumption. Thus, utilities will have a strong impact on natural gas pricing with decontrol.

In table 4 , an analysis of natural gas decontrol is constructed using the set of energy prices prevailing at the end of 1981; this can be referred to as the conventional analysis because it assumes that oil prices will be unaffected by decontrol. In the table, the price of natural gas for electric utilities is assumed to rise to that of residual fuel oil on a BTU-equivalent basis. The resulting rise in the price of natural gas limits the increase in wellhead prices under decontrol to $\$ 2.22$ per thousand cubic feet (mcf), a doubling of such prices. At the residential level, such a wellhead price increase would raise the delivered price from $\$ 4.85 /$ mof to $\$ 7.07 / \mathrm{mcf}$, about a 46 percent increase.
A recent estimate of the price effects of continued phased decontrol (NGPA continuing after 1984) indieates an addition to overall nominal and relative energy prices of 1.2 percent per year, adding less than 0.1 percent to the rate of increase in the GNP deflator from 1982 through 1986. With complete decontrol in early 1983 , but with energy prices the same as at the end of 1981 , the price level would rise 0.4 percent within about one year, so that the inflation rate temporarily would be 0.4 percentage points higher. ${ }^{10}$

This price level effect arises because higher real energy costs reduce productivity or potential output through reduced energy usage and increased obsolesm cence of domestic capital and labor resources. The extent of these effects is trivial in comparison to the effects of the two OPEC energy shocks in 1973-74 and $1979-80$.

More important, however, this analytic approach is itself woefully incomplete, because it ignores the efficiency gains in the use of existing natural gas and the effects of decontrol on the world energy market. In particular, potential users of natural gas value it far more highly than indicated by the controlled price, and decontrol provides incentives to make it available.

\footnotetext{
${ }^{10}$ Immediate decontrol also removes the relatively trival upward adjustment in the prices of goods and services that otherwise would have continued under the control solution of phased decontrol See Ott and Tatom, "Are There Adverse Inflation Effects?"
} 
As a result, total energy is more abundant and should become cheaper relative to all other goods and services. Yet, in the conventional analysis, the reverse occurs.

\section{NATI 基}

Industrial users and electric utilities currently are restricted in their purchases of natural gas. As a result, they are forced to use fuels like oil or coal that are more costly, In many industrial processes and in electric generation, fuel substitution possibilities are technically unlimited, but additional gas cannot be obtained due to direct legal restrictions. The contribution of energy to the value of output is correctly measured by the price of oil that firms pay, and this is the relevant measure of fuel cost that enters into the determination of prices of output including electricity. Such firms could profitably pay up to the current price of fuel oil for the energy equivalent in natural gas; for each unit of gas substituted, oil use and oil imports would decline by the amount of oil that is not purchased.

Currently, some residential users are not allowed access to natural gas. As a result, they too are forced to rely on higher-cost fuel alternatives. Like industrial or utility users, they would be willing and able to pay much more for gas than the current price, and, if such a switch were allowed, they would reduce their purchases of higher-cost altemative fuels such as electricity, fuel oil or coal. ${ }^{11}$

With no change in natural gas production, decontrol would lead to gains in efficiency and aggregate output, and lower prices of final goods and services. Higher prices of natural gas would tend to reduce gas use by those who currently are able to obtain all the gas they wish to use. This gas would be diverted to users who value natural gas more highly, but can only buy gas if residential and commercial customers do not. Overall energy prices clearly will fall for purchasers who currently cannot buy gas or are limited in their ability to purchase it, and they will reduce their reliance on higher-cost alternative fuels.

\footnotetext{
"Bennett and Kuenstner, "Natural Gas Controls" show that the number of annual new residential gas customers declined sharply after 1970, from abou 800,000 per year from $1960-69$ to under 400,000 per year from 1975-77. Following phased decontrol and its attendant supply increases, hook-ups rose by more than 200,000 per year from 1978-80. Conversions to resilential gas heating also were rationed under controls, declining from abont 400,000 per year from 1960-69 to under 100,000 in 1977 . Subse quently, these conversions surged to almost 600,000 per year by 1980.
}

These substitutions reduce the demand for OPEC oil. Given the pattern of use of natural gas, differences in the responsiveness of demand by residential and other users of natural gas, and prices that prevailed at the end of 1981 , for each 1 percent rise in the delivered price of natural gas for industrial and electric utility purchasers, the demand for OPEC oil would decline by 0.4 percent. $^{12}$

Decontrol allows gas prices to rise, providing an incentive to boost domestic gas production and displace some of the U.S. and world oil demand with U.S. gas, further reducing the demand for OPEC oil. Decontrol also increases the responsiveness of U.S. gas and energy supplies to changes in the world price of oil. A domestic price ceiling on domestic natural gas results in a completely unresponsive or inelastic supply of gas. Producers market only the amount that is profitable to produce at the fixed price. Increases or decreases in the world price of oil or energy result in no direct changes in the incentive to produce domestic gas. When the price ceiling is lifted, the responsiveness of demand facing other producers of energy, especially OPEC, rises, putting downward pressure on their prices.

A price leader, dominant firm in an industry, or a cartel is limited in its incentive to raise prices by the supply response of other producers and by the demand response of purchasers, since higher prices reduce the quantities demanded and increase the quantities supplied by competitors. ${ }^{13}$ The OPEC cartel has benefited

\footnotetext{
12This estimate is derived in Ott and Tatom, "Are There Adverse Inflation Effects?" based on econometric evidence in Robert $\mathrm{S}$. Pindyck, The Structure of World Energy Demand Massachusetts Institute of Technology Press, 1979).

13 The relevant theory of pricing applied here for the OPEC cartel is often referred to as the theory of the dominant firm. This is the theoretical basis for the results in $O t t$ and Tatom, "Are There Adverse Inflation Effects?". For a more detailed discussion, see George J. Stigler, The Organization of Industry (Richard D. Frwin. Ine, 1968) or his The Theory of Price, 3rd ed. (Macmillan, 1966), especially chapter 13 , appendix $B$ and mathematical note 7 . This theory has been ased for OPEC in the studies cited in footnote 1 above, and in fohn A. Tatom, "Energy Prices and Capital Formation, 1972 1977," this Review (May 1979), pp. 8-9; Steven E. Plant "OPEC Is Not a Cartel" Challenge NovemberDecember 1981), pp. 18-24; and Rodney T. Smith, "In Search of the 'Just' U.S. Oil Policy: A Review of Arrow and Kalt and More, Journal of Business (January 1981), pp. 87-116. Other discussions of OPEC pricing behavior include those in William D. Nordhaus, "Oil and Economic Performance in Industrial Countries," Brookings Papers on Economic Activify (2:1980), up. 341-99; Robert S. Pindyck, "Some Long-Tern Problems in OPEC Oil Pricings," Journal of Energy and Development (Spring 1979), pp. 259-72, E. Hnyilica and R. S. Pindyck, "Pricing Policies for a two-part exhatistible resomrce cartel: The case of OPEC," Eturopean Eco" nomic Review (Angust 1976), gp. 139-54; and Philip K. Verleger, "The Determinants of Official OPEC Crude Prices," The Reviet of Economics and Statistics (May 1982), pp. 177 83.
} 


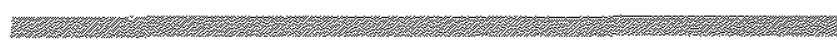

Figure 1

\section{The Demand for OPEC Oil}

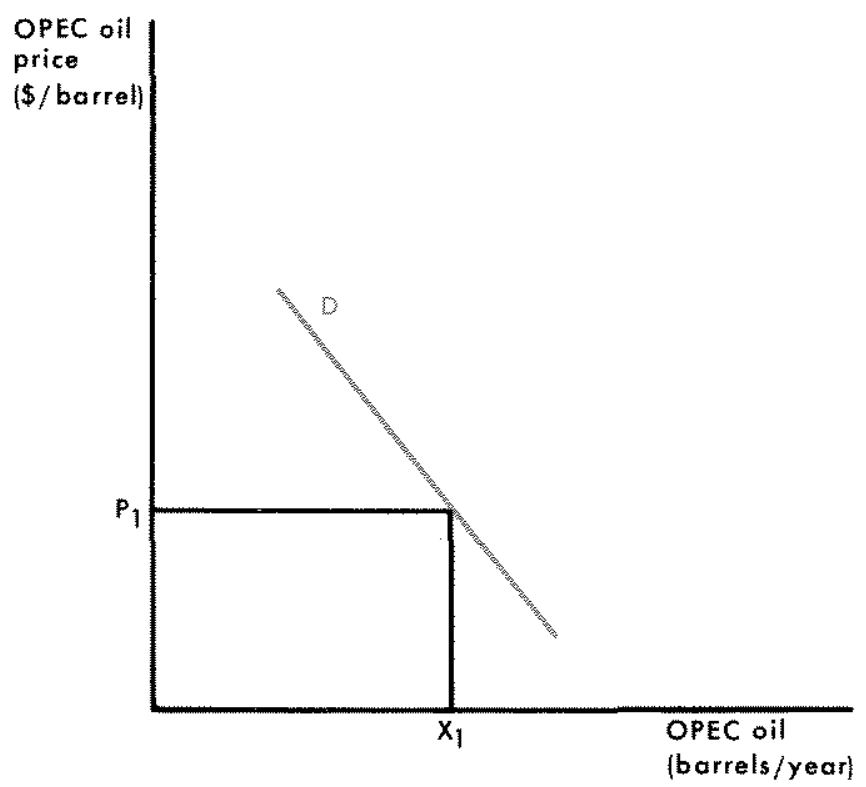

from U.S. natural gas price controls because its price increases are not automatically matched by increased U.S. natural gas prices that would evoke larger gas supplies, and because the demand for OPEC oil is larger under U.S. natural gas price controls. As a result, OPEC has found it attractive to raise prices more than they would have if U.S, energy producers could compete with OPEC. ${ }^{14}$

Three factors, then, lower the world price of oil under U.S. natural gas decontrol: interfuel substitution, increased domestic energy production, and an increased responsiveness of U.S. energy production to changes in the world price of oil. These factors reduce the demand for OPEC oil and raise the responsiveness of the demand for OPEC oil to OPEC price changes.

The effects on the demand for OPEC oil and its price arise from some simple considerations of economic theory. World energy prices have been determined largely by OPEC oil prices since 1973; OPEC faces competition, however, from competing producers of oil, as well as from producers of close substitutes such as natural gas, coal and nuclear power. In this environment, a cartel acts as a "dominant firm," realizing that

\footnotetext{
The analysis here assumes that OPEC acts as a dominant firm, but is unaffected if only some members of OPEC are the residual suppliers and price-setters while others are "price-takers," that is, producing all they desire at the OPEC price, like non-OPEC producers of oil.
}

other producers will produce and sell as much of their products as they desire given the economic environment, including the OPEC oil price. Thus, OPEC faces a derived demand that, at each price of oil, is the difference between world demand for oil and the energy supply of other producers.

Given factors other than price that influence the demand for OPEC oil, a demand curve such as that shown in figure 1 can be derived. At higher prices, OPEC demand is smaller, because some competing producers of oil produce more and purchasers of world oil buy less. The latter reaction arises for two reasons: some asers restrict activities in which they use oil, and other users switch to a more abundant supply from competing non-oil energy producers. OPEC, a dominant firm, sets its price for oil, taking these interactions into account as well as its cost of producing oil so as to maximize wealth (essentially the present value of its oil reserves). At such an optimal price, $P_{1}$ in figure 1 , OPEC producers sell all the oil demanded of them.

As a result of an effective ceiling price of natural gas, the supply of U.S. natural gas is smaller, and the U.S. and world demand for oil is larger than it otherwise would be. In addition, the responsiveness of world oil demand to changes in the OPEC price is reduced. The OPEC demand is larger (the curve is further to the right) and steeper under price controls. When the OPEC price rises above $P_{1}$, world oil demand and the residual portion facing OPEC cannot fall as much because there can be no increase in U.S. natural gas to compete with OPEC oil at higher energy prices.

Decontrol would reduce the component of U.S., world and OPEC oil demand created by controlled natural gas prices. The demand would shift from $\mathrm{D}$ to $\mathrm{D}^{\prime}$ in figure 2. Moreover, the responsiveness of OPEC demand would be increased so that the demand at price $P_{1}$ would become more responsive to OPEC price changes than under price controls. At any price, OPEC would find that their total receipts were more responsive to price changes. If the OPEC price is raised from $P_{1}$ along $D^{\prime}, U$, S. natural gas prices would respond to individuals' attempts to use more gas and less oil, and U.S. natural gas producers would respond by producing more. If the OPEC price were lowered, sales of OPEC oil would expand more because some energy users would switch from U.S. natural gas to oil, natural gas prices would fall in line with oil, and U.S. natural gas producers would cut back production.

Both types of changes in the demand for OPEC oil would induce a lower price. Reductions in the market share of a dominant firm cause a bigger wealth loss if 
Figure 2

\section{U.S. Natural Gas Decontrol and Demand for OPEC Oil}

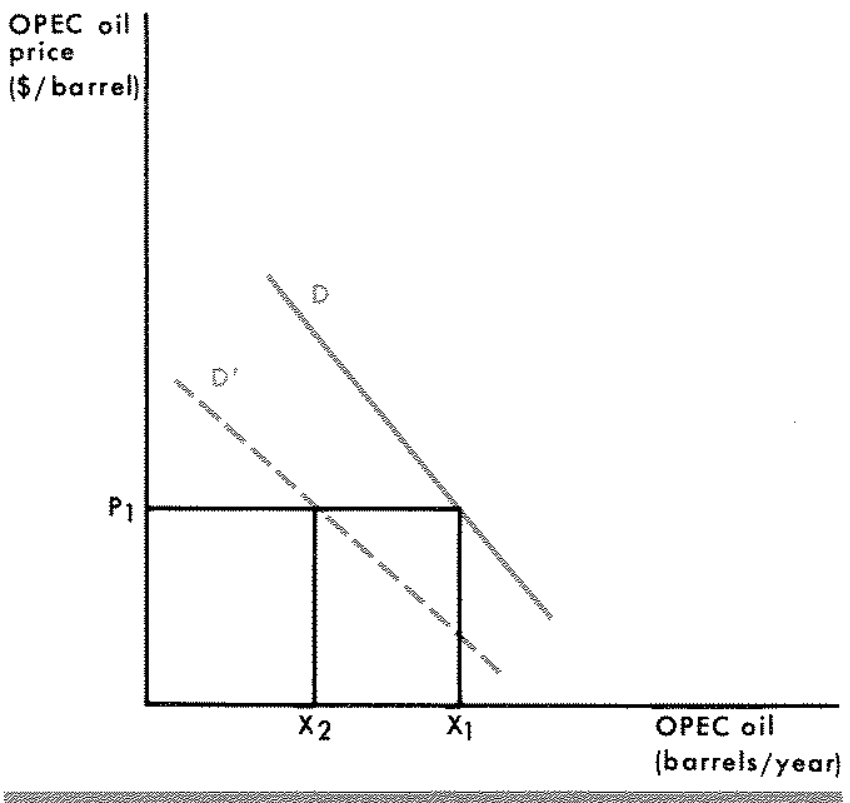

prices are kept the same than if some of its market share is recouped by lowering the oil price somewhat and passing the revenue loss on to competing producers of oil and energy. In effect, OPEC would replace the output of their competitors as well as filling any increase in energy demand due to the lower energy prices with enlarged OPEC production. In addition, the revenue increase from any $\mathrm{OPEC}$ price cut would be enhanced, because OPEC could displace high-cost U.S. natural gas through their pricing actions.

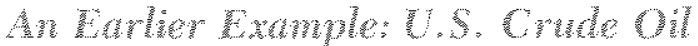 Irecontal}

The decontrol of the U.S. market for crude ofl in February 1981 provides a usefil test of these hypotheses. ${ }^{15}$ In that instance, the analysis is simpler and the eflects are smaller than would be the case with natural gas decontrol. Prior to decontrol, domestic crude oil prices were determined through an entitlement system so that oil sold for the same weighted average price for amost all purchasers, regardless of the source. Thus, the allocation of controlled oil was more efficient than is currently the case with natural gas; each purchaser paid the same price for crude oil. This meant there was no artificially induced demand for crude oil created by restricting the availability of the controlled

\footnotetext{
1.5 See also Tatom, "Energy and Its Impact on Economic Growth."
}

crude to some purchasers. At a price above the controlled price received by sellers of domestic crude but below the import price, any purchaser could buy as much or as little crude oil as desired.

In other respects, however, the analysis is virtually the same: decontrol allowed domestic production and prices to be responsive to world prices. As a result, the demand for OPEC oil fell, given the OPEC price, as U.S. oil purchasers reduced quantities demanded and U.S. producers expanded the quantities supplied. More important, the effective responsiveness of U.S. oil producers to changes in OPEC prices was increased. Thus, the demand for OPEC oil shifted as described in fignre 2, leftward and flatter. Both changes reduced the OPEC price.

The sequence of oil price movements in the United States following decontrol was dramatic. In Febratary 1981, the cost of imported crude oil to refineries was $\$ 39.00$ per barrel, while the cost of domestic oil in January, the month prior to decontrol, was $\$ 32.71$ per barrel. At the time of decontrol, there was concern that domestic prices of oil would rise to eliminate the discrepancy between domestic and imported oil. The domestic oil cost did rise, but peaked at $\$ 36.97$ per barrel in March. The world price, however, fell steadily, as did the domestic price atter March. Within five months, the average cost of crude oil had fallen below its level in the month before decontrol. In June 1982 , the average refiner acquisition cost was below the controlled domestic price in Fanuary 1981; that is, the free-market U.S. price and the wold price were lower than the controlled U.S. price had been in the month before decontrol. From the first quarter of 1981, when decontrol occurred, to the thind quarter of 1982, the refiner acquistion cost of imported oil fell 14.4 percent, despite a rise in the U.S. price level of 9.7 percent; that is, the real price of imported or world oil has fallen 22 percent since decontrol.

Some observers attribute the recent decline in real oil and energy costs to the worldwide recession rather than the decontrol of the U.S. crude oil market. Such a view is inconsistent with the historical evidence. Before 1974 , the producer price index for crede oil and for fuels, related products and power (defated by the implicit price deflator for business sector output) exhibited no cyelical tendencies, at least in terms of a significant statistical relationship to measures of slack stich as the Federal Reserve Board index of capacity utilization or the unemployment rate.

Chart 2 shows the U.S. refiner acquisition cost of imported oil deflated by the business sector deflator 


\section{Chart 2}

\section{Real Oil Prices 4}

\section{(1972 dollars)}

\section{Dollars per barrel \\ Dollars per barrel}

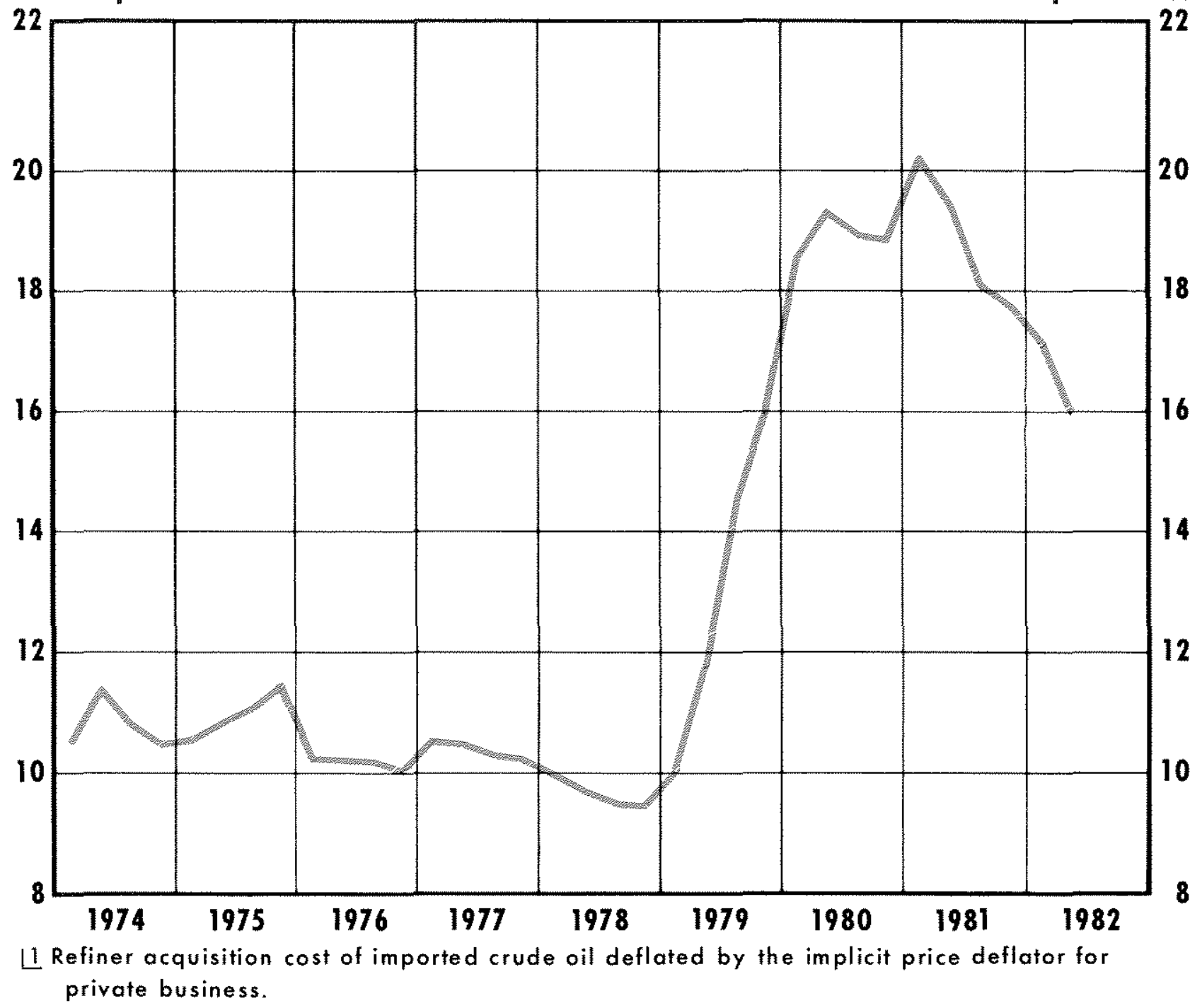

from 1974 to the second quarter of 1982 . The real price of oil during the period of OPEC control has not been cyclical, contrary to the recent cyclical explanation of falling OPEC prices. For example, a cyclical view would have required a falling price in the 1974-75 recession and rising prices during the cyclical expansion from 1976 to 1980 . Contrary to this view, chart 2 shows a slight downtrend in prices from 1974 to the end of 1978, a sharp rise in 1979 and early 1980 and again in early 1981. Until the first quarter of 1981, the pattern is easily explained by a moderate erosion of the dominant firm's market share in the oil and energy markets due to competition and then, when the output of Iran and Iraq declined sharply after 1978 , by a major rise in demand faced by other OPEC members. ${ }^{16}$

\footnotetext{
${ }^{16}$ Cyclical movements in world oil prices, however, are not inconsistent with the underlying economic theory. Given prices a cvical decline in world oil demand falls principally on the OPEC market share. Becatse the responsiveness of demand for OPEC oil is raised by suct a change, a cyclically lower world price would be optimal. The point above, however, is that the possibility for such cydical movements has been dominated by other developments
} 
Table 5

Energy Price Effects of Natural Gas Decontrol

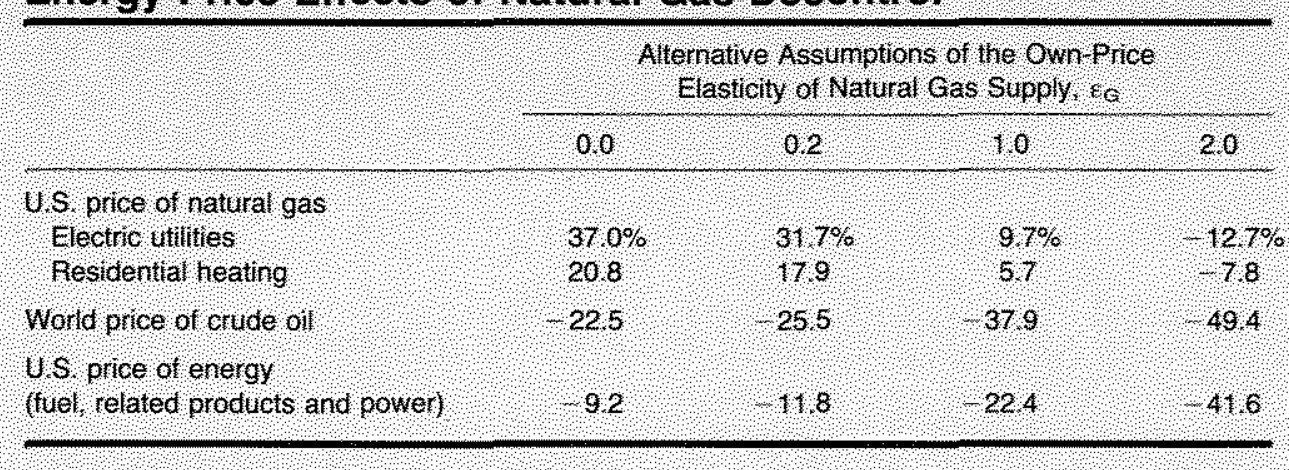

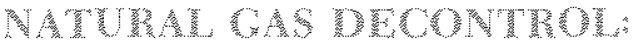 MA

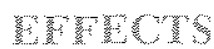

The extent of the decline in the world price of oil due to decontrol depends on the responsiveness of $\mathrm{OPEC}$ oil demand to changes in the $O P E C$ price, the responsiveness of U.S. natural gas supply to changes in the U.S. price of natural gas, and the effect of decontrol on the former. The OPEC oil demand is more responsive (elastic) to changes in the OPEC price, the larger the responses of world demand for oil or competitors' energy supplies to changes in the OPEC price, or the smaller the market share of the price-setter in the world oil market.

Many behavional parameters are required to estimate the pattern of oil and gas price changes that occur when decontrol closes the gap between oil and gas prices. Depending on the magnitude of these parameters, the gap will be closed by relatively more downward pressure on oil prices, and less upward pressure on gas prices. Indeed, if the responsiveness of U.S. natural gas supply is large enough, the gap will be closed, with oil prices declining to equal a lower price of U.S. natural gas.

For a broad range of parameter estimates, the price of natural gas rises substantially less than a conventional estimate like that in table 4 . More important, under no plausible conditions does the overall index of energy prices rise due to decontrol; the depressing effect of decontrol on the world oil price and, hence, on the prices of all petroleum products and other competing energy sources outweighs any upward effect of decontrol on the price of U.S. nattral gas. ${ }^{17}$

\footnotetext{
The downward pressure on oil prices dominates any upwart pressure on gas prices because, while U, S. production of oil and
}

For example, table 5 reports the percentage changes in the U.S. relative price of natural gas, the world relative price of crude oil, the U.S. relative price of energy, and the price of gas for residential heating with some standard assumptions about the relevant responses. ${ }^{18}$ The effect of the size of responses of U.S. natural gas supply to changes in its price, the ownprice elasticity of U.S. natural gas supply $\left(\varepsilon_{\mathrm{G}}\right)$, is shown by considering four values ranging from no response whatsoever $\left(\varepsilon_{\mathrm{G}}\right.$ is 0 ), to a farly sizable response ( $\varepsilon_{\mathrm{G}}$ is 2). ${ }^{19}$ The first column of table 5 shows that, for a completely unresponsive natural gas supply, the gap between gas and oil prices is closed by fairly similar

gas are similar on a BTU basis, ol consumption is much larger, especialy in production of marketed output. The hypothesized dectine in overall energy mrices due to decontrol is quite robust and virtually independent of parameter assumptions. In the appendix to Ott and Tatom. "Are There Adverse Inflation Effects" equation 1.6, suffictent (not necessary) conditions for a fall in energy prices are that the U.S. elasticity of supply of natural gas exceed that for oil and that the elasticity of demand for $O P E C$ oil is less than 2 . Of the many unresolved dehates on the size of energy maket parameters, these two are perhaps the most readily agreed upon.

${ }^{16}$ These assumptions include an elasticity of world ol demand of 0.5 an elasticity of supply for competitors of 0.2. and a market share tor OPEC set at the relatively low level in W/1981 of 39 percent. The later assumption reduces the magnitude of the oil price response sabstantially. Altemative parameter values are discussed in the appendix to Ot and Tatom, "Are There Adverse Inflation Effects?"

${ }^{15}$ The percentage change in the supply of U.S. natural gas is a function of the percentage point rise in its price, so that a 10 percent rise in the U.S. natural gas price is assumed to increase supply by 0 percent, 2 percent, 10 percent or 20 percent, if $\varepsilon_{\mathrm{g}}$ is 0 , 0.2 . 1.0 or 2.0 respectively, Punl A. MacAvoy and Robert $\$$. Pindyck, "Alternative Regulatory Policies for Dealing with the Natural Gas Shortage," The Bell Journal of Economics and Management Science (Autumn 1973), pp. 45498 , and Machvoy and Pindyck. The Economics of the Natural Gas Shortage, present evidence that shows this elastecty is unity under a phased decontrol experiment. Uader immediate decontrol, it woukl be larger for reasons given in footnote 2 
increases in the price of natural gas for electric utilities and decreases in world oil prices. Even without a response by U.S. natural gas producers to decontrol, chergy prices decline.

At the other extreme in which natural gas supply is quite responsive, all prices are shown to decline sub stantially; the decline in energy prices is about the same magnitude as the increases associated with each of the two OPEC price shocks since 1973. There exists an intermediate supply elasticity, an $\varepsilon_{C_{r}}$ of 1.6 , at which the natural gas price would be the same after decontrol as its controlled level ${ }^{20}$ Focusing on the middle elasticities, most of the effect of decontrol is to lower oil prices rather than raise gas prices, with energy prices declining by between one-eighth and one-quarter.

The macroeconomic effects of decontrol are considerably smaller and less sensitive to the parameter assumptions. Natural gas decontrol, based on prices prevailing at the end of 1981, would lower the relative price of energy. The principal macroeconomic effects would be to lower the general level of prices and to raise potential output. For the middle two cases in table 5 , the price level quickly declines 1.1 to 2.2 percent, so that a like reduction temporarily occurs in the inflation rate in the year following decontrol, Capacity outpet and productivity are raised by similar amounts equally quickly. Due to a rise in the profitability of plant and equipment associated with lower energy prices, investment also would be raised temporarily, further increasing capacity output and productivity. The long-rum effect of natural gas decontrol is to raise capacity output and productivity by 1.5 to 3 percent.

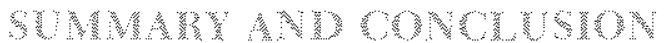

Natural gas decontrol cannot raise the price level. To raise prices of goods and services, decontrol would have to raise the relative price of energy resources and, thereby, reduce real output. The relative price of energy is determined in world markets and is based on the scarcity of energy resources. Since decontrol cannot reduce the energy supply, it camot raise energy prices or the price level.

We have examined the conventional analysis of decontrol that assumes real oil prices are unaffected by

\footnotetext{
201ntrigungly, an estinated elasticity of supply of new gas of 1.6 for the Oklahoma intrastate market was obtained by Chong Liew and Donald Murry, "An Econometric Model of The Intrastate Gas Market in Oklahoma," in Paul R. Lowry and Shirley Stanphill, Regional Supply and Demand of Coal and Petroleum for Energy Production (Burean of Business and Economic Research, Memphis State University, 1979).
}

U.S. energy policy. Under this worst-ase scenario, wellhead prices would double, and delivered prices of natural gas would rise under immediate decontrol by up to 50 percent, raising the general level of prices by about 0.4 percent within one year, temporarily adding a like amount to measured inflation. When the effect of increased competition in world energy markets is taken into account, however, such a conclusion is reversed. Decontrol reduces the demand for OPEC oil, lowering the world price of oil and energy prices in the United States, even if natural gas prices are higher. Increases in natural gas prices are not even inevitable. Plausible values of the elasticity of U.S. natural gas supply could lead to a substantial increase in competition in the world energy market and lower the optimal price for world oil by more than the existing discrepancy between gas and oil prices.

The confusion over the price effects of natural gas decontrol arises from an incorrect analogy to the two surges in the real price of OPEC oil over the past decade. Decontrol of gas reduces the scarcity of energy resources rather than increasing it, so the correct analogy is the experience with decontrol of the U.S. crude petroleum market in 1981, which lowered world energy prices.

Relative gas prices may fall ander decontrol but the more likely scenario is that they will rise 9.3 percent to 27.5 percent in relation to the prices of goods and services generally, while overall relative energy prices, as a result, will decline by about 12 percent to 25 percent. The analysis of energy effects on the macroeconomy leads to the conclusion that potential output will be raised as a result of decontrol by 1.5 percent to 3 percent, and the general level of prices would tend to be 1.1 percent to 2,2 percent lower than otherwise within about one year of full decontrol.

We have not been concerned here with the distribur tional implications of natural gas decontrol, but the general pattern of adjustments includes switching from gas to other forms of energy in many areas of production (and in residential uses), while users of gas that currently are constrained, especially industrial users and electric utilities, will tend to switch foward gas. The distributional effects of decontrol that arise from this broader analysis indicate that the issue is not consumers versus energy producers. ${ }^{21}$

\footnotetext{
2Tor a discussion of distribution effects of matural gas decontrol under the conventional assumption that oil prices are unaffected. seed J. A. Stodkfsch," The Income Distribution Effects of a Natural Gas Price Increase, "Contemporary Policy Issues, a supplement to Economic Inquiry (October 1982), pp. 9-25. For intertegional distribution effects, see Kalt, Lee and Leone, "Natural Gas Decontrol: A Northeast Industriat Perspective."
} 
Some consumers (those who use relatively more gas and relatively less electricity, coal, oil and oil products both directly and in the goods and services they pur chase) are likely to be affected adversely by natural gas decontrol. Other consumers (for example, users of relatively more gasoline and electricity both directly and in the goods and services they purchase) will benefit from decontrol.

Among energy producers, it is important to distinguish owners of wells from processors. Processors, such as gas pipeline companies and gas distribution companies, will likely face reduced profit margins temporarily and smaller markets, while gas well owners could gain by decontrol. In the oil sector, the refiners" market would tend to expand, improving profit margins temporarily, while owners of oil wells (including OPEC wells) will tend to be affected adversely by the removal of the component of their demand created by the regulatory constraint on competitors.

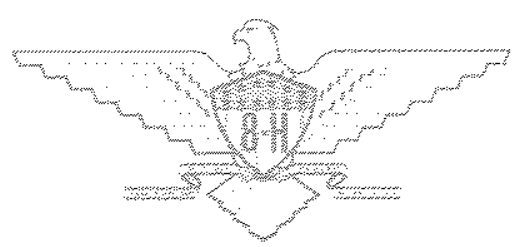

